\title{
Development of lignocellulosic fiber reinforced cement composite panels using semi-dry technology
}

\author{
K. M. Faridul Hasan (1) P Péter György Horváth · Tibor Alpár
}

Received: 15 November 2020/Accepted: 5 February 2021 / Published online: 22 February 2021

(C) The Author(s) 2021

\begin{abstract}
There is a growing interest in developing cement bonded lignocellulosic fiber (LF) composites with enhanced mechanical performances. This study assessed the possibility of developing composite panels with $12 \mathrm{~mm}$ thickness and around $1200 \mathrm{~kg} /$ $\mathrm{m}^{3}$ nominal densities from ordinary Portland cements (OPC) and mixed LFs from seven different woody plants found in Hungary. Once the mixed LFs were sieved and found fine $(0-0.6 \mathrm{~mm})$ and medium $(0.6-0.8 \mathrm{~mm})$ length fibers. The optimum ratio for LF, OPC, water glass $\left(\mathrm{Na}_{2} \mathrm{SiO}_{3}\right)$, and cement stone was found to be 1:3.5:0.7:0.07. The semi-dry process, which is a comparatively cheaper and less labor intensive technology, was used for producing the composites. After 28 days of curing, the composite panels were characterized for mechanical, physical, thermal, and morphological properties. A scanning electron microscopy (SEM) test was conducted to
\end{abstract}

observe the fiber orientation in the matrix before and after the bending test, which showed the clear presence of the fibers in the composites. The FTIR (Fourier transform infrared spectroscopy) was conducted to investigate the presence of chemical compounds of LF in the composite panels. Different physical (water absorption and thickness swelling) characteristics of the composite panels were investigated. Furthermore, mechanical properties (flexural properties and internal bonding strength) of the composite panels were also found to be satisfactory. The flexural modulus and internal bonding strengths of composite panel 2 is higher than other three boards, although the flexural strength is a little lower than composite panel 1 . The thermogravimetric analysis and differential thermogravimetry also indicated better thermal stability of composite panels which could be used as potential insulation panel for buildings.

K. M. F. Hasan $(\bowtie)$ · P. G. Horváth · T. Alpár $(\bowtie)$

Simonyi Károly Faculty of Engineering, University of

Sopron, Sopron, Hungary

e-mail: k.m.faridul.hasan@phd.uni-sopron.hu

T. Alpár

e-mail: alpar.tibor@uni-sopron.hu 


\section{Graphic abstract}

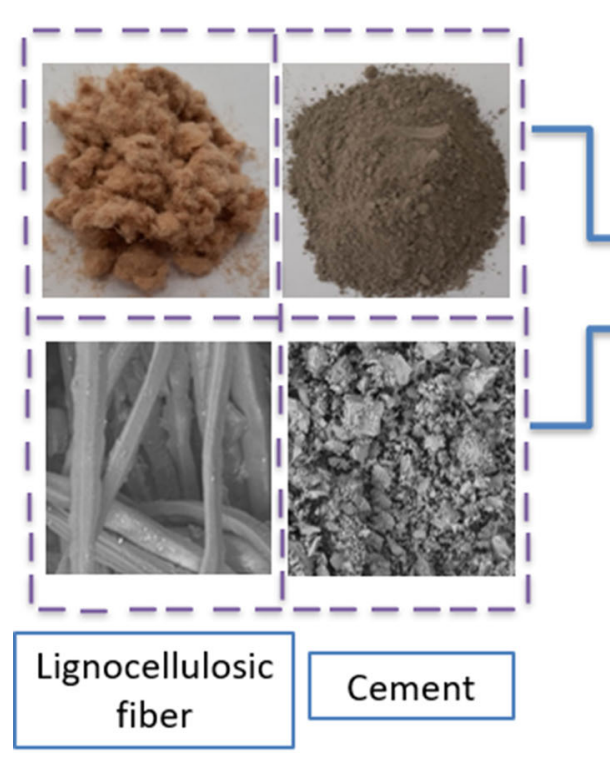

Keywords Lignocellulosic fiber/cement composite Mechanical performance Physical properties . Biocomposites · Curing

\section{Introduction}

Composite materials possess excellent potential for construction and building applications, particularly in environmental and economic perspectives. The need to replace hazardous materials with environmentfriendly products is a growing concern around the world. Natural fiber-based composites have become popular for their superior sustainable features, with plants being the main sources of LFs (Ferreira et al. 2017; Hasan et al. 2020b, c, 2021b; Kumar et al. 2018; Phomrak and Phisalaphong 2020; Sood and Dwivedi 2018). Cellulose, hemicellulose, and lignin are the main chemical components of LFs (Hasan et al. 2020a; Mahmud et al. 2021). Scientists have begun to focus on cement bonded natural fiber-based composites for their feasible characteristics. However, some

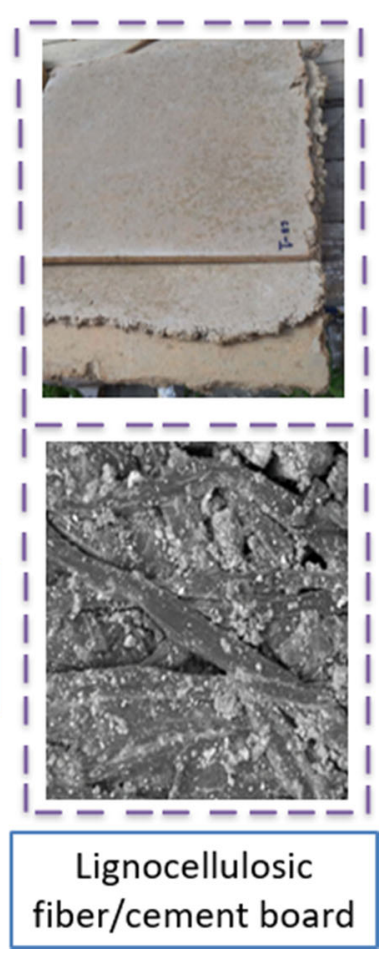

challenges concerning the compatibility issues between natural fiber and cement continue to linger (Bilcati et al. 2018; Li et al. 2020; Marques et al. 2016). The cements are not easily compatible with the fibers because of the presence of some inhibitory materials such as tannin, sugar, starch, phenols, hydroxylated carboxylic acid, and so on (Fan et al. 2012; Hasan et al. 2021a). Consequently, researchers are attempting new methods and technologies to improve compatibility (Arifuzzaman and Kim 2015; Quiroga et al. 2016). Fiber pretreatment and the use of better compatible additives have received much attention in this regard. Nevertheless, viable fiber treatment methods are still limited, and the addition of this method could incur an extra production cost during the composite manufacturing process. Hence, one of the prime objectives of this research was to produce cement bonded fiber boards through the use of more compatible additives rather than through any additional fiber pretreatment. Therefore, $\mathrm{Na}_{2} \mathrm{SiO}_{3}$ was used as an additive in fiber board manufacturing. Using chemical admixtures like $\mathrm{Na}_{2} \mathrm{SiO}_{3}$, aluminum silicate $\left(\mathrm{Al}_{2}\left(\mathrm{SO}_{4}\right)_{3}\right)$, calcium chloride $\left(\mathrm{CaCl}_{2}\right)$, and 
magnesium chloride $\left(\mathrm{MgCl}_{2}\right)$ accelerates the curing process of wood particles/fibers and cement-based composites (Alpár and Rácz 2009; Tichi et al. 2019). For this reason, the current investigation attempted to develop wood-based LF cement composites using different proportions (weight-based) of $\mathrm{Na}_{2} \mathrm{SiO}_{3}$. Every recipe uses the same proportion, which was developed and derived in line with industrial wood cement particle board production, albeit using a different semi-dry technology. On the other hand, $\mathrm{Na}_{2} \mathrm{SiO}_{3}$ was used for Scots pine and poplar wood particles with cement and different additives $\left(\mathrm{Na}_{2}\right.$ $\mathrm{SiO}_{3}, \mathrm{CaCl}_{2}$, and calcium formate) to develop wood cement composites (Alpár and Rácz 2009). However, the aforementioned report was limited to two different types of wood that had different proportions, but kept the additives (like water glass) and cement constant. To that the end, the current study aimed to investigate the performances of different proportions of LF and cements.

The LFs were collected from different species of mixed wood (beech, Turkey oak, pines, hornbeams, poplar, oak, and some other species) from a local Hungarian company. Researchers have previously developed some wood cement composites using the above mentioned types of wood, either individually or by mixing a few types together (Amiandamhen et al. 2016; Ashori et al. 2012; Kostić et al. 2018; Na et al. 2014; Papadopoulos 2008); nevertheless, the mixing of more than six woody plant-based composites has not yet been studied with sodium silicate and OPC. Beech was the highest proportion of the mixed plant LFs used in previous research. Within these plants, poplar (second highest constituent plant of LF) could significantly enhance the mechanical properties in mixed fiber cement composite panels (Ashori et al. 2011). Pine is another major constituent (20\%) of the LF materials, offering the potential to produce lighter weight panels (Amiandamhen et al. 2016). Thus, poplar and pine combined with other plant fibers could increase the mechanical strength and efficiency of composites. In addition, many studies have investigated the properties and optimum compatibility ratio of LF/cement boards without fiber treatment in the interest of reducing extra-processes, chemicals, and energy consumption. In general, cementitious materials possess poor tenacity, which leads to composite cracking/fracture when force is applied (Soroushian et al. 2012; Wei and Meyer 2015); however; this problem could be overcome through the use of LFs as prominent raw materials in the composites. Although they are shorter in size, LFs also increase impact strength, tensile strength, and flexural rigidity in cement bonded composites (Pereira et al. 2020). LFs also coordinate the reduction of board density (Karade and Aggarwal 2011). In general, fiber-cement boards are produced via the wet (Hatchek) process (Akhavan et al. 2017; Ranachowski and Schabowicz 2017), but in this research, the experimental boards were made through the semi-dry process similar to the production processes of cement-bonded particleboards (Ezerskiy et al. 2018b). Although the semi-dry process is widely used for cement bonded particle board production (Ezerskiy et al. 2018a; Takats and Takats 2012) (Simatupang and Geimer 1990), natural fibers have not been implemented to produce cement bonded fiber composites. Compared to the traditional fiber/cement composite production, the semidry process is a much cheaper technology, one requiring less capital and labor investment than the spray dewatering technique (Evans et al. 1981).

In recent decades, researchers have reported some findings for investigations into the alternative manufacturing methods for cement bonded LF composites. The current study focused on using the raw LF material without making any additional surface modifications before composite formation by utilizing the semi-dry method. The current work also aimed to investigate the optimum proportions of fiber cement for composite panel manufacturing. The flexural and internal bonding strength was performed to assess the mechanical performances of the composites. The thickness swelling and water absorption tests were also conducted for the assessment of stability against water. The TGA, DTG, FTIR, and sieving tests were also performed on manufactured composite panels.

\section{Materials and methods}

\section{Materials}

The LF from mixed woody plant species (Fagus sylvatica, Quercus cerris, Pinus spp., Carpinus betulus, Populus spp., Quercus robur, and others) with different percentages (Table 1) was collected from Kronospan-MOFA Hungary Ltd., Hungary. The morphology and images of the LF and cements are 


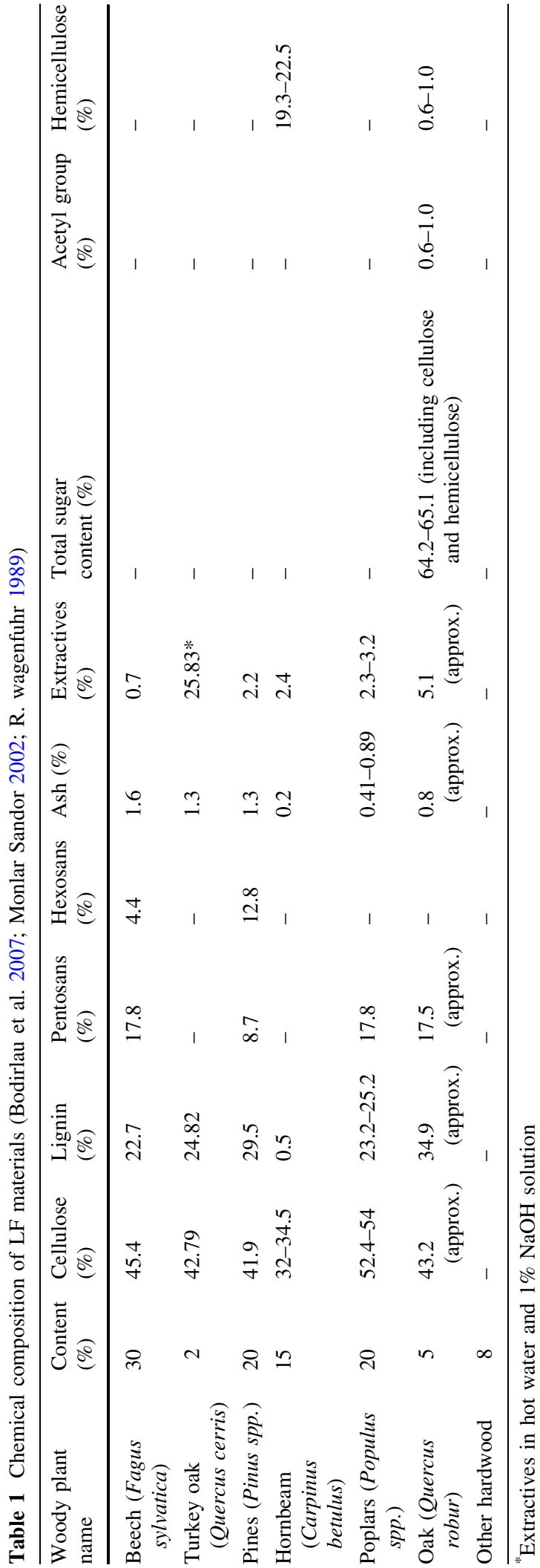

shown Fig. 1. The constituents for the LFs rank as follows: beech ranks as the highest constituent with $30 \%$; pine and poplar are $20 \%$ each; hornbeam is $15 \%$; oak is $5 \%$; Turkey oak is $2 \%$; and other types of woods are $8 \%$. The $\mathrm{pH}$ value of Turkey oak is 4.9 , whereas other hardwoods (like quercus) have 3.3-3.9. Accordingly, $8 \%$ of other hardwoods were added to produce the LFs to prevent increased acidity in the fibers, which may interrupt the hydration process between the fiber and cement. Conversely, when water is mixed with cement, it becomes alkaline ( $\mathrm{pH} 9.0$ and more), so the addition of more oak could help to reduce $\mathrm{pH}$. Cellulose and lignin are the major constituents of LFs, as provided in Table 1. Compared to the other woody plants, poplar contains the highest cellulose (52.4-54\%). Among the types of wood, oak contains the highest content with $34.9 \%$, while hornbeam contains the lowest, with only $0.5 \%$. However, woody plants also contain pentosans, hexosans, ash, extractives, sugar, acetyl group, and hemicellulose in variable amounts. Chemical compositions of woodbased fibers are vital for the compatibility of the fiber cement composites. The presence of higher extractives impede fiber cement compatibility (Na et al. 2014), but the selected species for LFs exhibit $0.5-3.2 \%$ extractives, with the exception of oak, which exhibits $5.1 \%$. The fiber for the investigation did not receive any additional pretreatment and was used in the same state as it was received. The OPC CEM I 42.5, which was used as cement materials, was collected from a local Hungarian manufacturer. $\mathrm{Na}_{2} \mathrm{SiO}_{3}$ was purchased from Sigma Aldrich, Hungary.

Methods

The LFs were spread out on a table at ambient conditions (temperature $20{ }^{\circ} \mathrm{C}$ and relative humidity $65 \%$ ) for $24 \mathrm{~h}$ to reach equilibrium with the environmental atmosphere. Once this was achieved, the moisture contents of the LFs were measured with a Kern ULB 50-3 N (KERN AND SOHN GmbH, Balingen, Germany) through the gravimetric method. The LF granules (less than $1 \mathrm{~g}$ ) were evenly sprayed over the balance pan of the analyzer to ensure accurate moisture content measurements. The drying temperature was $105 \pm 0.3{ }^{\circ} \mathrm{C}$ with no changes in mass and balance measurement accuracy $(0.001 \mathrm{~g})$. The test method EN 322:1993 was employed for this characterization. The average moisture content of the fiber 

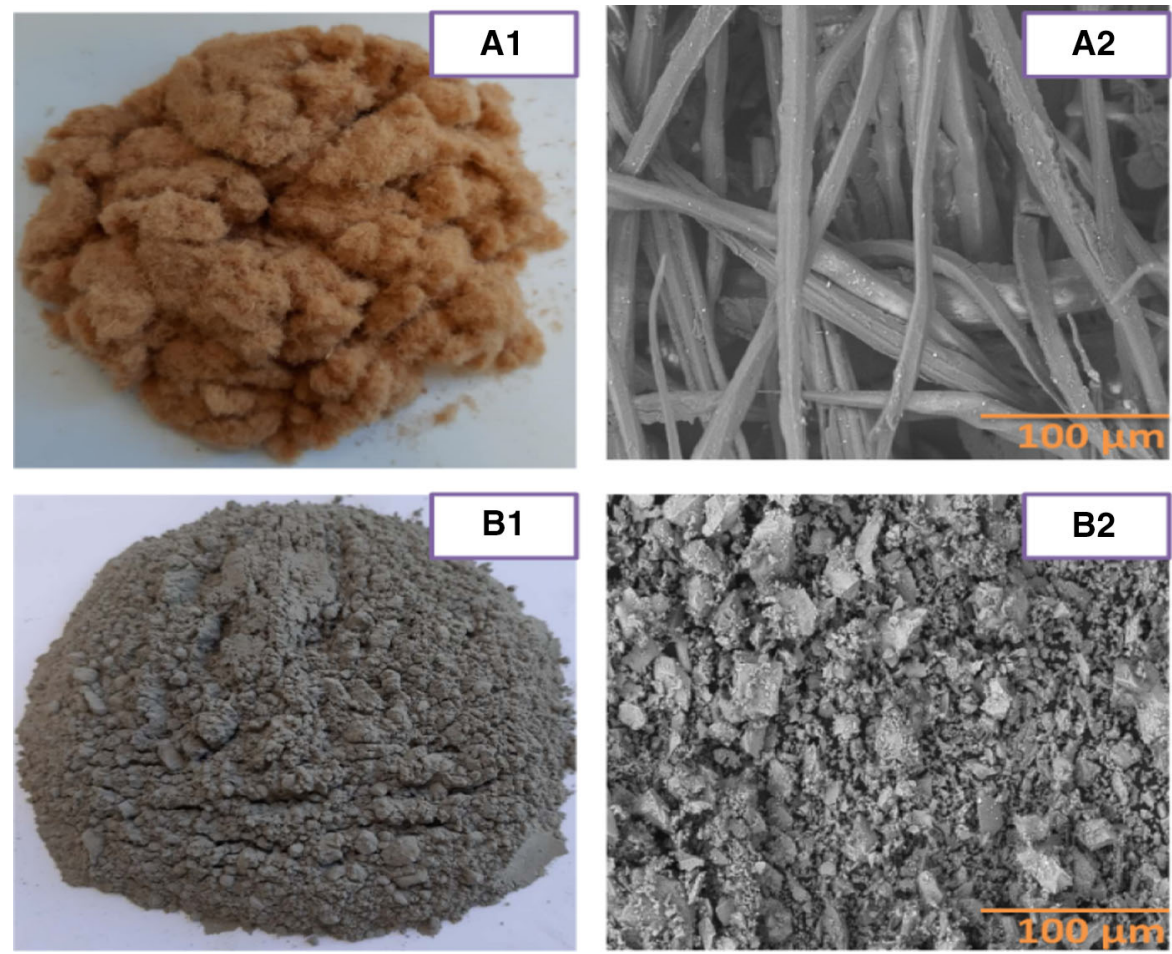

Fig. 1 A 1 Physical images of LFs; A2 SEM morphology of LFs; B1 Physical images of OPC; B2 SEM morphology of LFs

was $7 \pm 0.3 \%$ (for 5 random tests). The sieve analysis was performed by a sieve analyzer before composite production (Fig. 2) for $50 \mathrm{~g}$ of the fibers with six different sieves. Sieving time was $15 \mathrm{~min}$. The fibers were distributed within 0 and $800 \mu \mathrm{m}$ ranges. Four cement bonded LF boards (CBFB) were prepared by varying the OPC proportions $(2.6 \%, 3.5 \%, 3.7 \%$, and 4\%) through a pressing machine as shown in Table 2 [G. Siempelkamp GmbH and Co. KG., (Krefeld, Germany)]. The proportion of fibers remained fixed by $1 \%$ (although it changed with the varying of cement percentages), whereas the $\mathrm{Na}_{2} \mathrm{SiO}_{3}$ was varied for different boards by $0.052,0.07,0.074$, and $0.08 \%$, respectively as shown in Table 2 . The recipes were proportions derived from the industrial wood cement particle boards. Although the recipes are proportional, the mentioned proportions were measured in weight (g) for individual composite panels. The used water proportion was $50 \%$ for mixing in terms of total dry matter content. In addition, the quantity of water was calculated based on board density and dimension along with the moisture content of LFs and

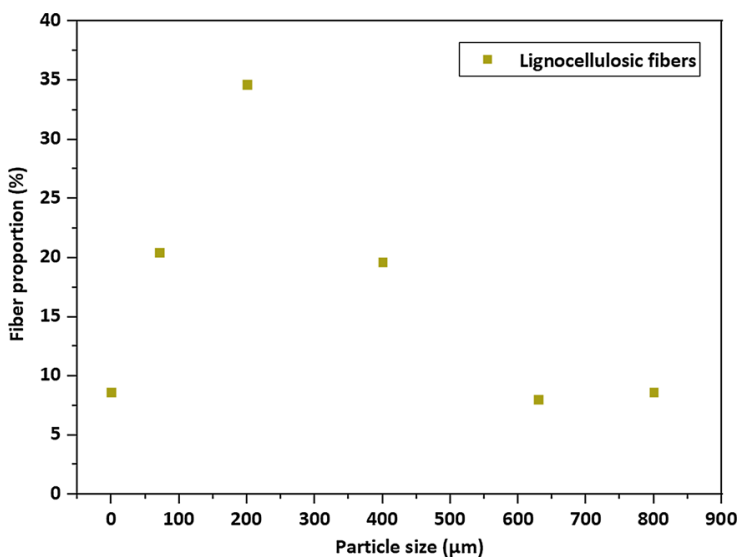

Fig. 2 Size distribution of lignocellulosic fibers

Table 2 Recipe for CBFB production

\begin{tabular}{lllll}
\hline $\begin{array}{l}\text { Chemical/ } \\
\text { Materials }\end{array}$ & $\begin{array}{l}\text { Recipe } \\
1\end{array}$ & $\begin{array}{l}\text { Recipe } \\
2\end{array}$ & $\begin{array}{l}\text { Recipe } \\
3\end{array}$ & $\begin{array}{l}\text { Recipe } \\
4\end{array}$ \\
\hline LF & 1 & 1 & 1 & 1 \\
Cement & 2.6 & 3.5 & 3.7 & 4 \\
Water glass & 0.052 & 0.07 & 0.074 & 0.08 \\
Cement stone & 0.52 & 0.7 & 0.74 & 0.8 \\
\hline
\end{tabular}


$\mathrm{Na}_{2} \mathrm{SiO}_{3}$. The assumed (nominal) densities of the four fiber boards were $1300 \mathrm{~kg} / \mathrm{m}^{3}$ each.

The measured LFs, OPC, water, and additives were mixed properly to prevent the formation of any fiber/ cement lumps. In this regard, the LFs were put into a steel drum and continuously stirred with an electric mixer while OPC was gradually poured on them. The mixed LFs and OPCs were mixed for an additional $2 \mathrm{~min}$ to ensure uniform mixing. Later, the mixed $\mathrm{Na}_{2} \mathrm{SiO}_{3}$ and water solution was also gradually poured into the drum. The stirring was continued constantly during the entire mixing process. Finally, the stirring was continued for additional $2 \mathrm{~min}$ to ensure homogeneous mixing of fiber, cement, $\mathrm{Na}_{2} \mathrm{SiO}_{3}$, and water. Hence, slurry was formed. After the mixture was prepared, it was mixed manually and poured uniformly into a $400 \times 400 \mathrm{~mm}^{2}$ wooden frame and pressed by another wooden lid once the fiber/cement mat had formed. After that, $12 \times 12 \mathrm{~mm}^{2}$ steel rods were placed around the pressed LF/cement matrix to produce the boards with expected thickness during the pressing. This was then covered by a polybag, covered by another steel plate, and transferred to the pressing machine. The applied specific pressure in the pressing machine was $8.2 \mathrm{MPa}$, which was maintained for $24 \mathrm{~h}$. Finally, the board was taken out from the machine and cured for 28 days to ensure better curing of the cements. The same procedure was followed for the remaining three cement boards. six fiber boards were produced for each individual recipe. All four composites were also tested six times for each individual test. The Instron 4208 (Instron Corporation, USA) testing machine was used to investigate the results of flexural properties and internal bonding strengths of the produced LF/cement composites. Testing standard EN 319 was applied for the internal bonding strength analysis. The speed of crosshead movement during the internal bonding strength was $0.8 \mathrm{~mm} / \mathrm{min}$. The standard adopted for flexural strength was EN 310 and crosshead movement speed was $5.0 \mathrm{~mm} / \mathrm{min}$. The FTIR characterization was performed by FT/IR-6300 model (Jasco, Tokyo, Japan). The SEM, Hitachi, S $3400 \mathrm{~N}$ was utilized for studying the surface morphology of the LF/cement composites at accelerating voltage of $15 \mathrm{kV}$. The thermal stability of the LF, cement, and associated composites were measured using Themys thermal analyzer (TGA, Setaram Instrumentation (Kep
Technologies), France) within $25-800{ }^{\circ} \mathrm{C}$ temperature under nitrogen atmosphere at $10^{\circ} \mathrm{C} / \mathrm{min}$.

\section{Physical properties determination of LF/cement boards}

Physical properties (water absorbency and thickness swelling) of fiber cement composite were tested after $2 \mathrm{~h}$ and $24 \mathrm{~h}$ of water immersion. The main objective of this test was to investigate the weight gain after water immersion. It is necessary to measure the test specimens after water immersion while the constituting polymers of the composites are saturated. So, $24 \mathrm{~h}$ of ultimate immersion was performed for the physical tests. The thickness swelling (TS) test was conducted according to the EN 317 procedure and the water absorption test was performed as per Hungarian standards (MSZ 13,336-4:13,379). However, this water absorption test is nearly the same as EN 317 with the exception of the measurement of weight of the composite samples before and after the immersion into water. The sample dimensions were $50 \times 50 \mathrm{~mm}^{2}$. The water absorption of composite samples was calculated as per Eq. (2). The weights of the samples (six to each) of all the four boards were measured $\left(50 \times 50 \mathrm{~mm}^{2}\right)$ with an electric balance (Bizerba, SL$2100 \mathrm{M}$, Italy). Sample thicknesses were also measured at the same time using Mitutoyo 543-551D equipment (Mitutoyo Europe $\mathrm{GmbH}$, Neuss, Germany). All the four boards were then submerged into distilled water for $2 \mathrm{~h}$. After that, board samples were removed from the water, and weight and thickness values were measured. The boards were then immersed into the water for another $22 \mathrm{~h}$ (altogether $24 \mathrm{~h}$ ). Finally, thickness and water absorbance were measured again. The specimens were placed in an oven dryer for $24 \mathrm{~h}$ at high temperature $\left(105^{\circ} \mathrm{C}\right)$. The weight of each sample was measured before and after drying for the calculation of moisture content (EN 322 standard) as shown in Eq. (1).

Moisture content $($ time $)=\frac{M_{w}-M_{d}}{M_{d}} \times 100$

where $M_{w}$ is the weight of the wet sample, $M_{d}$ is the weight of dry samples. Time interval is $2 \mathrm{~h}$ and $24 \mathrm{~h}$.

The following Eq. (2) was used to measure the water absorbency of the samples.

Where, $\mathrm{W}_{\mathrm{w}}$ is the weight of wet sample, $\mathrm{W}_{\mathrm{d}}$ is the weight of dry samples, and time ( $t$ ) is same with 
moisture content such as $2 \mathrm{~h}$ and $24 \mathrm{~h}$ period of intervals.

Water absorbance $($ time $)=\frac{\mathrm{W}_{\mathrm{w}}-\mathrm{W}_{\mathrm{d}}}{\mathrm{W}_{\mathrm{d}}} \times 100$

The thickness swelling of LF/cement composite was measured by using the bellow Eq. (3):

Thickness swelling $($ time $)=\frac{T_{w}-T_{d}}{T_{d}} \times 100$

where $T_{w}$ is the thickness of the wet sample, $T_{d}$ is the thickness of the dry samples, and time is same with the water absorbance such as $2 \mathrm{~h}$ and $24 \mathrm{~h}$ intervals.

\section{Mechanical properties determination of LF/cement boards (EN 310)}

The mechanical properties for LF/cement composites were measured in terms of flexural strength, flexural modulus, and internal bonding strength. The $290 \times 50$ $\mathrm{mm}^{2}$ samples were placed in the Instron machine to test flexural properties. The load was applied perpendicularly at the center of the samples by maintaining a constant speed until breaking occurred. The internal bonding strength of the CBFB boards was also measured using the same Instron machine, albeit with a different design as per standard. The modulus of rupture for the fiber cement composite board was calculated based on the Eq. (4).

Modulus of rupture $=\frac{3}{2} \frac{F l}{b t^{2}}$

where $\mathrm{F}=$ maximum force/load in $\mathrm{N}, \mathrm{L}=$ span length in $\mathrm{mm}, \mathrm{b}=$ width of specimens in $\mathrm{mm}, \mathrm{t}=$ thickness of specimens in $\mathrm{mm}, \mathrm{a}=$ deflection.

On the other hand, the modulus of elasticity is calculated as per the Eq. (5).

Modulus of elasticity, $E_{m}=\frac{l_{1}^{3} \times\left(F_{2}-F_{1}\right)}{4 \times b \times t^{3} \times\left(a_{2}-a_{1}\right)}$

$l_{1}=$ span of support $[\mathrm{mm}], \mathrm{b}=$ width of specimen $[\mathrm{mm}], \mathrm{t}=$ thickness of specimen $[\mathrm{mm}], \mathrm{F}_{2}-\mathrm{F}_{1}=$ increase of load in $\mathrm{N}$ on the straight section of the loaddeflection curve. $\mathrm{F}_{1}$ at $10 \%$ of $\left(\mathrm{F}_{\max }\right), \mathrm{F}_{2}$ at $40 \%$ of $\left(F_{\max }\right) \cdot a_{2}-a_{1}=$ increase of deflection of the test pieces measured at the center of the test sample in connection with the increase in load $\left(\mathrm{F}_{2}-\mathrm{F}_{1}\right)$.

\section{Results and discussion}

Density is an important parameter to determine the mechanical properties of fiber cement composites. The composites with higher density (greater or equal to $1300 \mathrm{~kg} / \mathrm{m}^{3}$ ) provide higher mechanical strength (Antwi-Boasiako et al. 2018). Although the nominal densities of the composite panels were $1300 \mathrm{~kg} / \mathrm{m}^{3}$, the current study discovered the following actual densities: $1225.37,1376.24,1209.25$, and $1262.75 \mathrm{~kg} /$ $\mathrm{m}^{3}$, respectively (Fig. 3). The variation from nominal density may have been influenced by the manual mixing, compression, homogeneous distribution problems (LF, cement, water, and other chemical ingredients), and manual cutting of the test pieces. However, all of the boards still provided densities higher than $1200 \mathrm{~kg} / \mathrm{m}^{3}$. On the other hand, higher densities also reflect higher bonding between the fiber and cements in the matrix system (Zhou and Kamdem 2002). CBFB2 exhibits the highest density, so the highest internal bonding strength $(0.16 \mathrm{MPa})$ is also observed for this board when compared to CBFB1, CBFB3, and CBFB4. The lower mechanical characteristics of CBFB3 may be associated with the lower density $\left(1209.25 \mathrm{~kg} / \mathrm{m}^{3}\right)$ as well.

The flexural properties (bending strength and flexural modulus) of $\mathrm{LF} /$ cement composites are displayed in Fig. 4. The flexural characteristics of all the four boards are significantly different. CBFB1 and CBFB2 display comparatively higher flexural performances than CBFB3 and CBFB4. However, CBFB1 shows the highest bending strength (2.993 MPa) and

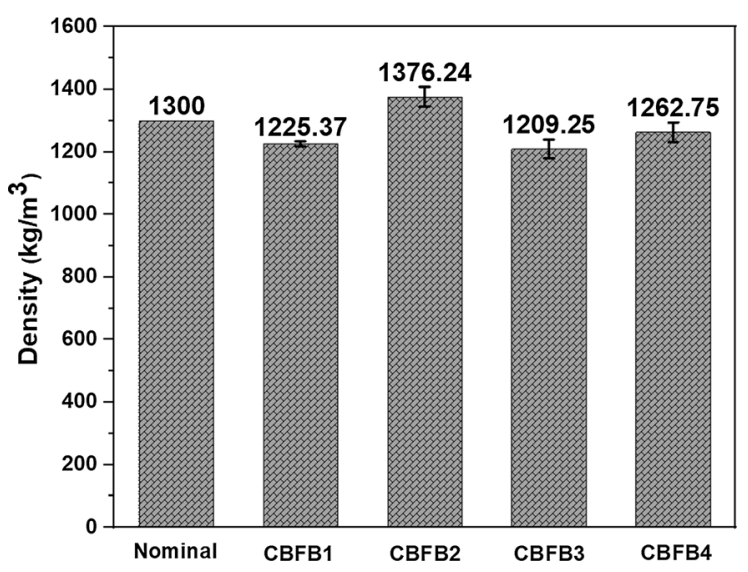

Fig. 3 Nominal and actual densities of the produced LF/cement boards 

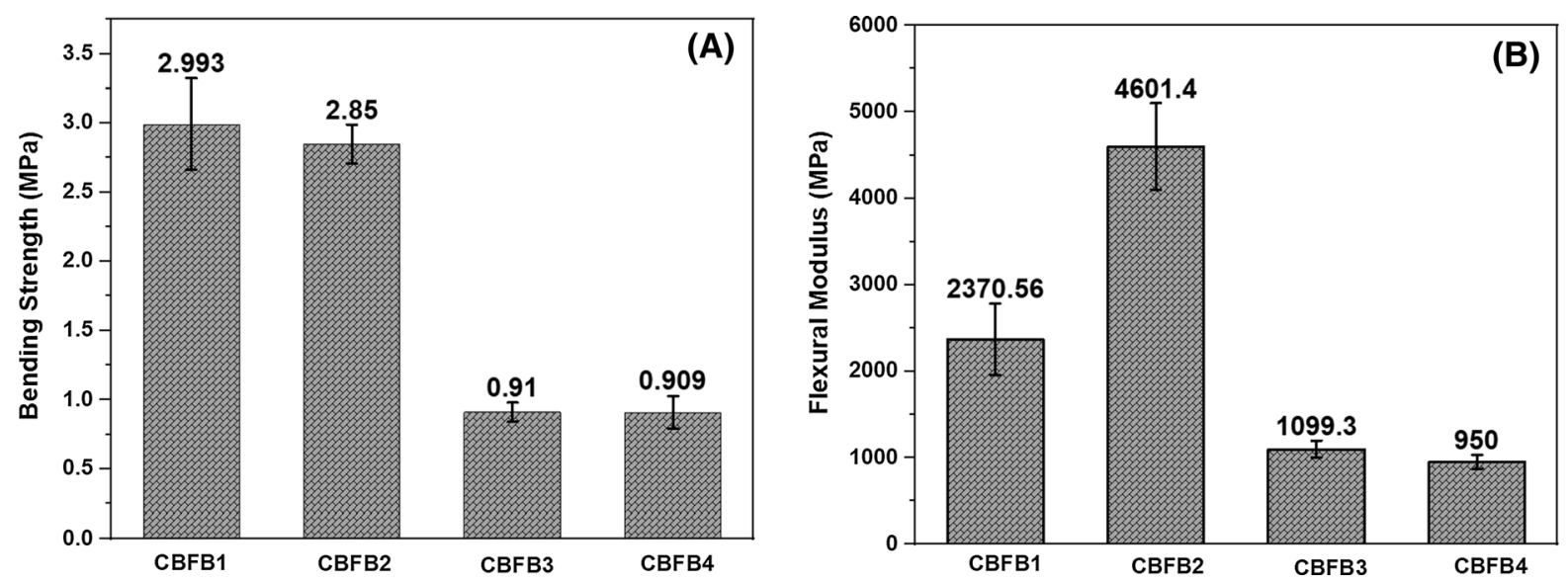

Fig. 4 Flexural characteristics of LF/cement composites: a Bending strength and b Flexural modulus

CBFB2 exhibits highest flexural modulus (4601.4 MPa) compared to the rest of the boards. Individually, CBFB2 provides better performance properties compared to all other boards. Conversely, CBFB3 and CBFB4 exhibit lower values for bending strength (0.91 and $0.909 \mathrm{MPa}$, respectively) and flexural modulus (1099.3 and $950 \mathrm{MPa}$, respectively), which may be due to the increased volume of cement content in the composites after achieving the optimum level for CBFB2. It seems that the LFs are more compatible with the cement from recipe 2 where the ratio of LF, cement, water glass, and cement stone was 1:3.5:0.07:0.7. Another research study reported similar results for untreated kraft softwood (Blankenhorn et al. 2001) reinforced composites. Yet another study also revealed flexural strengths within $0.91-2.46 \mathrm{MPa}$ for medium density fiberboard production (Małaszkiewicz and Sztukowska 2018).

The mean values of internal bonding strengths of different LF/cement composites are shown in Fig. 5. The internal bonding strengths ranged from 0.01 to $0.16 \mathrm{MPa}$. Composite panels CBFB1, CBFB3, and CBFB4 exhibited exceptionally poor internal bonding strengths compared to CBFB2. A similar outcome was also reported by other researchers in the production of wood and cement fiberboards (Małaszkiewicz and Sztukowska 2018). CBFB2 has exhibited the highest internal bonding strength $(0.16 \mathrm{MPa})$ compared to the other three composite panels. This may be due to the higher fiber cement compatibility at that proportion. The lower values of internal bonding strength reveal

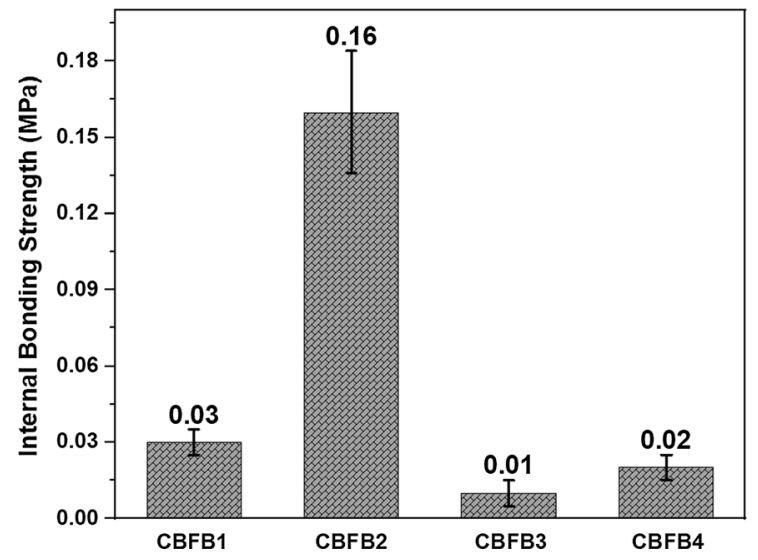

Fig. 5 Internal bonding strength of LF/cement composites

that the bond is weaker between the fiber, cement, and sodium silicate in the composite system. The debonding in the fiber matrix interface is responsible for poor internal bonding strengths, which was reported for kenaf fiber incorporated with cement (Basher 2013). Moreover, the reason behind the lower internal bond of CBFB3 and CBFB4 may be due to the addition of more cement, which increased the particle volume, but reduced the total composite volume. Additionally, the fiber-to-cement interaction may also affect the increased volume of cement. Consequently, the fiber and cement could not interact properly to create a strong bond in the composite systems (Ghofrani et al. 2015). However, the pretreatment of 


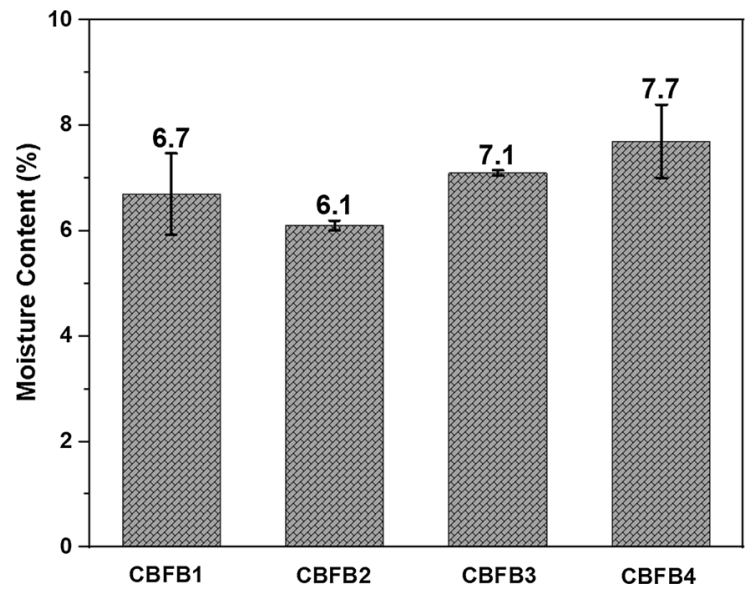

Fig. 6 Moisture content of LF/cement composites

fiber surfaces using suitable technology (like mercerization, silane, and so on) could enhance this property (de Klerk et al. 2020; Onuaguluchi and Banthia 2016).

The moisture content of the LF/cement composite is shown in Fig. 6. With the exception of CBFB2, the other panels-CBFB1, CBFB3, and CBFB4-all demonstrated increasing trends of moisture content. The highest moisture content appeared in CBFB4 (7.7\%) and the lowest in CBFB2 (6.1\%). Boards 1 and 3 exhibited moisture contents of $6.7 \%$ and $7.3 \%$, respectively. Other scientists have reported similar moisture content trends (Asasutjarit et al. 2007) too.

Water absorption is another important parameter for fiber cement composite panels as it may affect dimensional stability and mechanical performance. Although the water absorption test was conducted as per MSZ 13,336-4:13,379 standard, it is similar with the international standards. The water absorbency of the composite panels varied significantly. However, all the boards exhibited a similar increasing trend for the changes in water absorbency with the increase of cement percentages (which means the decrease of fiber proportion) in the matrix. The water absorbencies found in the current work were within 17.2-21.2\% after $2 \mathrm{~h}$ of water immersion. These increased to $22-27.06 \%$ respectively after $24 \mathrm{~h}$ of immersion, as shown in Fig. 7. Although fiber percentage in the matrix system remained the same, it decreased gradually with the increase of cement percentage as its a proportion from CBFB1 to CBFB4. These results are compatible with other research studies (Basher 2013; Ghofrani et al. 2015). As reported in the FTIR curve (Fig. 10), wood fibers contain hydrophilic compounds (cellulose and hemicellulose). Hence, there is a hydrogen bond created for the interaction between the hydroxyl group of the LF and water molecules. In addition, the water molecules are diffused into the interface of fiber and cement (Ghofrani et al. 2015).

Thickness swelling is another important physical property that ensures the dimensional stability of fiber cement composites. Thickness swelling provides directions similar to water absorbency. With the exception of board 2, thickness swelling values varied significantly for different boards in similar directions
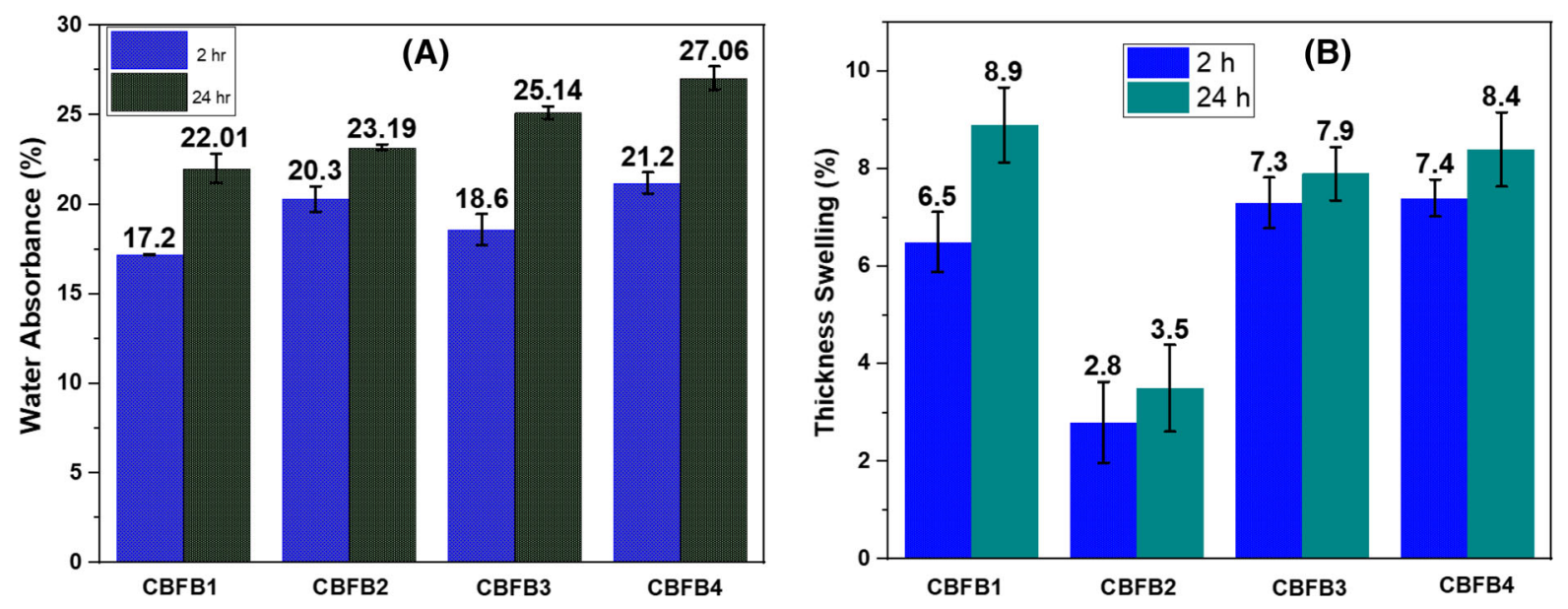

Fig. 7 Physical properties of LF/cement composites: a Water absorption and b Thickness swelling 
(increasing trend from board 1 to board 4) (Fig. 7B); however, after $2 \mathrm{~h}$ of water immersion, thickness demonstrated an increasing trend. This increasing trend applied after $24 \mathrm{~h}$ as well, which is illustrated in Fig. 7B. However, after $2 \mathrm{~h}$ of water immersion, thickness swelling was lowest for the CBFB2 (2.8\%) and highest for CBFB4 (7.4\%). This value was enhanced to $8.9 \%$ for CBFB1, but CBFB2 still remained the lowest $(3.5 \%)$ after $24 \mathrm{~h}$ of immersion. Other studies have reported similar results (Asasutjarit et al. 2007; Ghofrani et al. 2015; Soroushian and Hassan 2012).

The SEM micrographs of LF cement composites were investigated to assess morphology. The images (Fig. 8A-D) show the profile of LF and cement in the matrix system. The appearance of the fibers (pink arrows) could be easily observed in all the composites. However, the fibers are more explicitly apparent in CBFB1 and CBFB3 compared to CBFB2 and CBFB4. The fiber materials started to disappear in the matrix
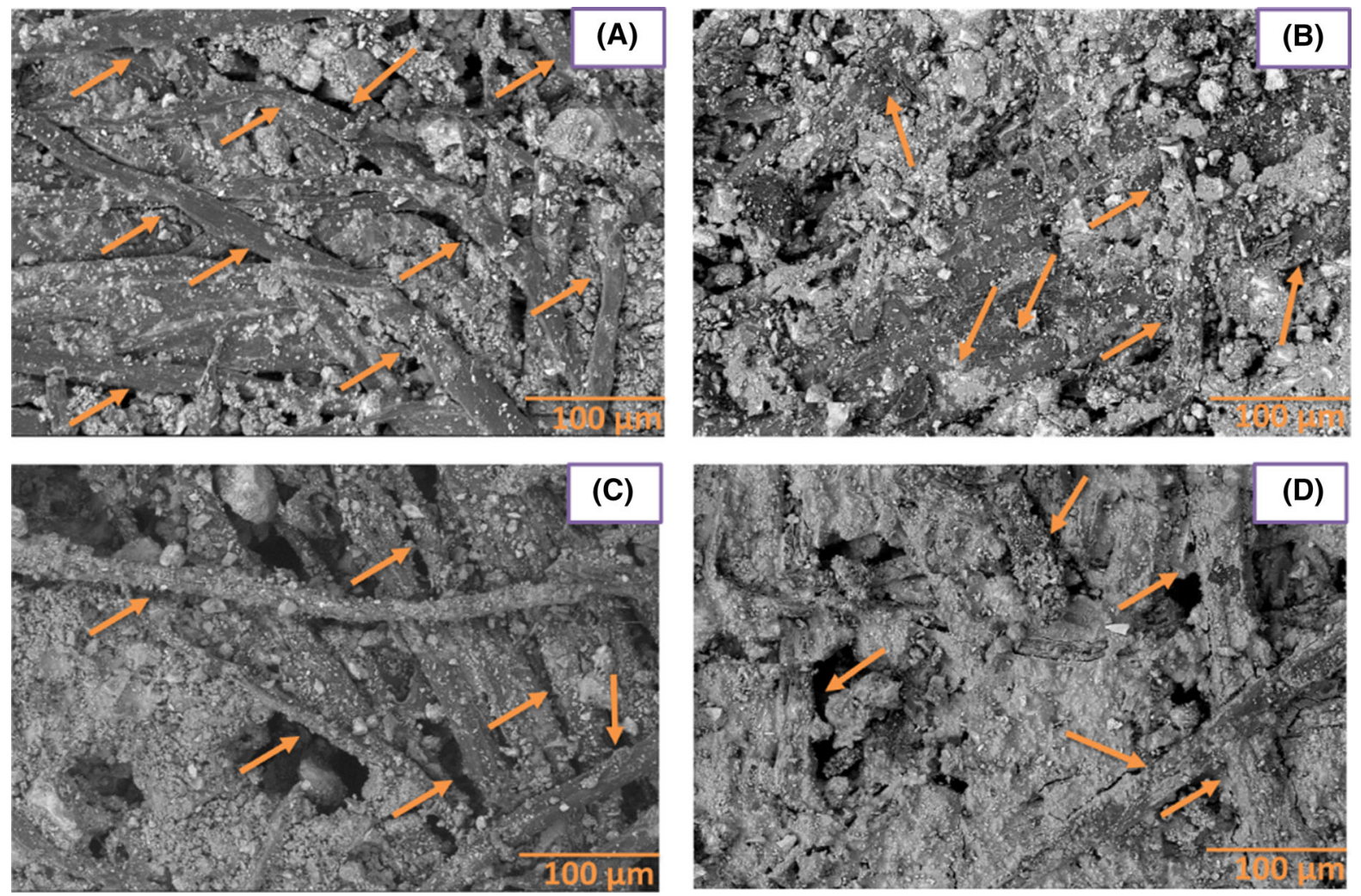

system with the increase in cement concentration, which is why the presence of fibers is difficult to observe in CBFB4 compared to CBFB1, CBFB2, and CBFB3. The fibers in CBFB2, appeared closer to the cement, which helps explain why the internal bonding strength of this board is seemingly higher compared to rest of the boards. It seems the fibers are more compatible with the cement for recipe 2 (LF:cement: water glass:cement stone $=1: 3.5: 0.07: 0.7)$ than it is with the other recipes. However, all the SEM images clearly demonstrate the uniform distribution of LFs throughout the matrix, which was also reported by other studies (Kochova et al. 2020a; Tichi et al. 2019). On the other hand, the delay of cracking occurred for the uniformly overlapped LF/cement in the matrix structure (Tichi et al. 2019). The cracked LF/cement surface in the matrix appeared as illustrated in Fig. 9a-d. The LFs were pulled out and fractured from the matrix when the stress was applied to the composites, a phenomenon that is also noticed on the

Fig. 8 SEM profiles of a CBFB1; b CBFB2; $\mathbf{c}$ CBFB3; d CBFB4 

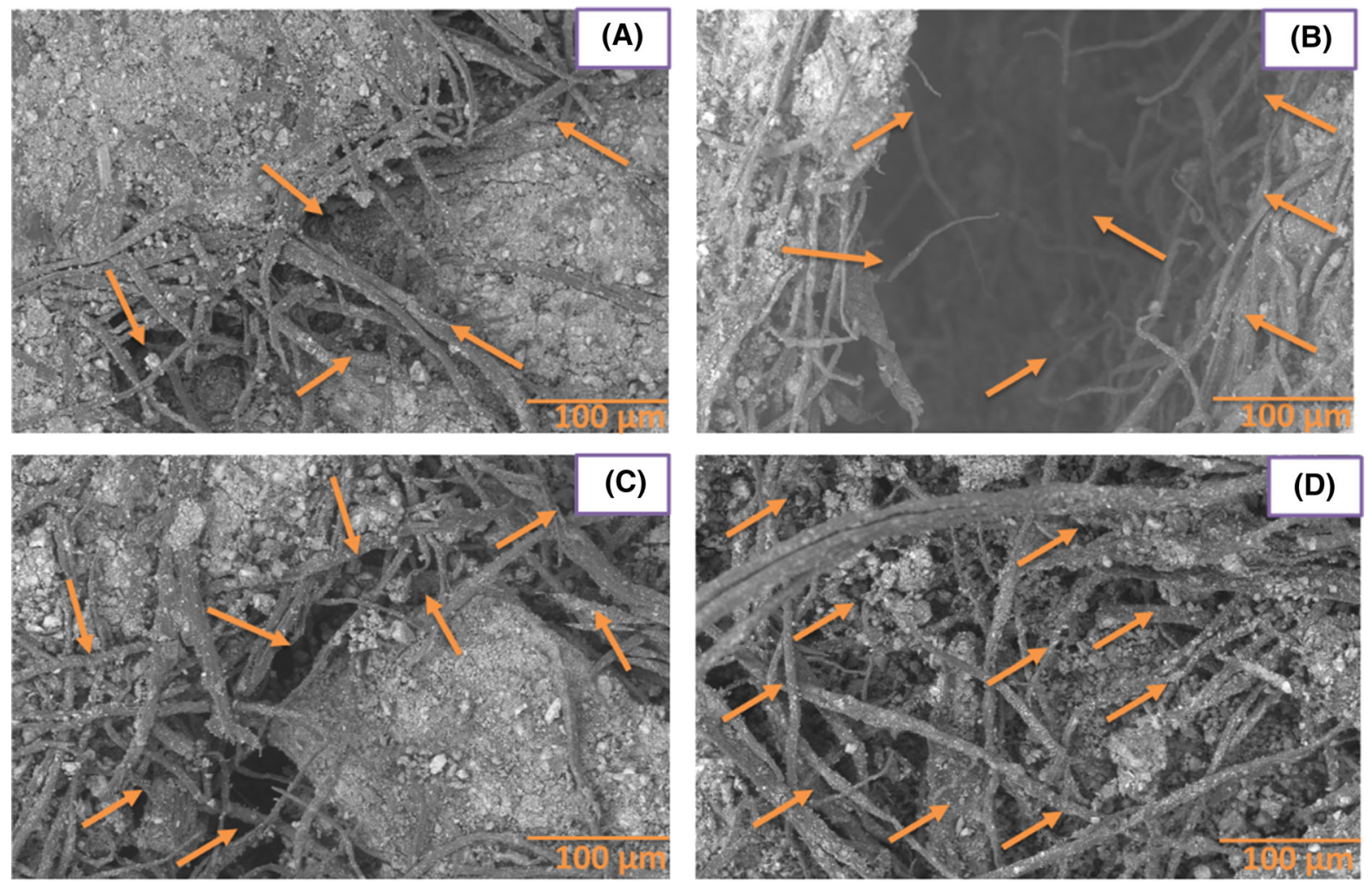

Fig. 9 SEM micrographs of fractured a CBFB1; b CBFB2; c CBFB3; d CBFB4 LF/cement composites

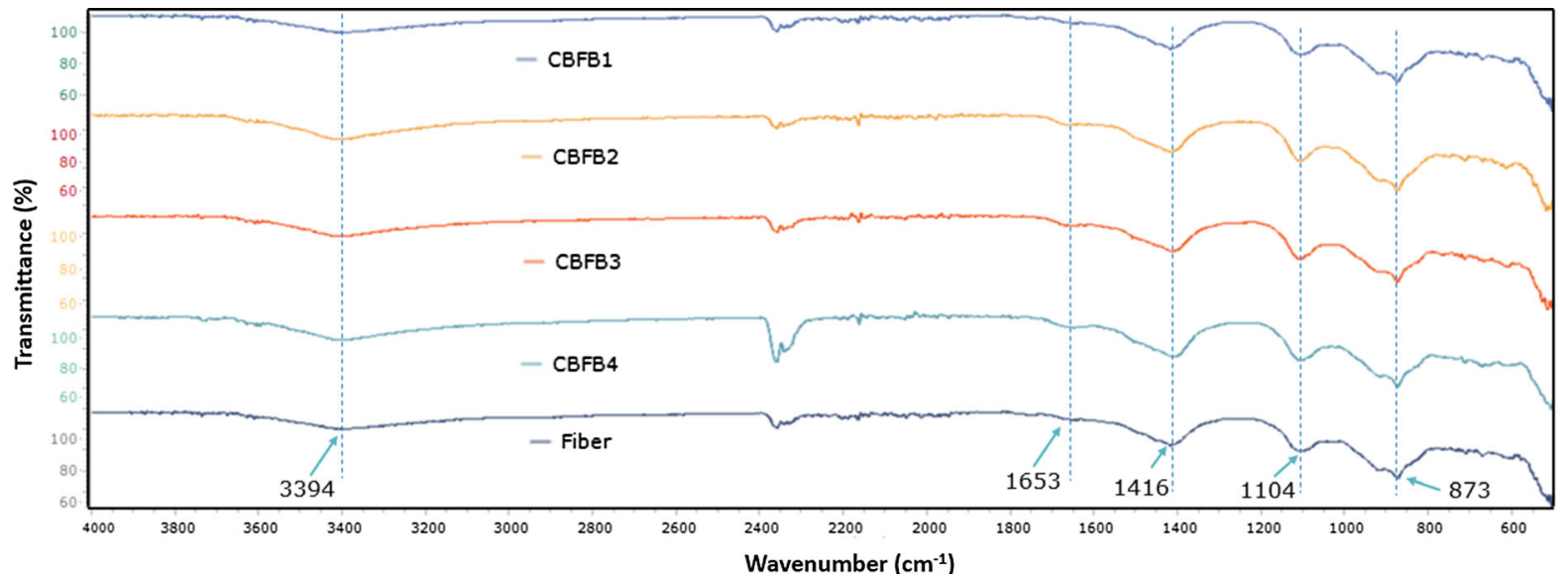

Fig. 10 FTIR spectra of LFs/cement composites $\left(4000-500 \mathrm{~cm}^{-1}\right)$

micrograph images. The similar trend was also reported by $\mathrm{He}$ et al. (2020).

The FTIR study $\left(4000-500 \mathrm{~cm}^{-1}\right.$ wavelength and $50-100 \%$ transmittance) clearly proves the existence of cellulosic fibers in the produced composite panels
(Fig. 10). The peaks at $3394-3609 \mathrm{~cm}^{-1}$ indicate the stretching vibrations of $\mathrm{C}-\mathrm{H}$ and $\mathrm{O}-\mathrm{H}$ into the LF. The peaks within the $800-1600 \mathrm{~cm}^{-1}$ range are attributed to the cellulosic structure of LF. The bands at $1416 \mathrm{~cm}^{-1}$ are associated with the crystalline area of 
cellulosic fibers and the amorphous region is ascribed by the peaks at $873 \mathrm{~cm}^{-1}$ (Hospodarova et al. 2018). Moreover, the peaks within $1104-1600 \mathrm{~cm}^{-1}$ correspond to the presence of hemicellulose and lignin (Kochova et al. 2020b). The control LF shows the presence of different chemical constituents of cellulose, hemicellulose, and lignin (Fig. 10). However, the reinforcement of LFs with OPC and $\mathrm{Na}_{2} \mathrm{SiO}_{3}$ could not affect the structure of the fibers in composite panels (Fig. 10). All the composite panels (CBFB1, CBFB2, CBFB3, and CBFB4) reflect the presence of LFs in their matrix system.

The curves for TGA and DTG analysis of all the CBFB boards are illustrated in Fig. 11. When the naturally originated cellulosic fibers are embedded with OPC, and exposed to the porous solutions three polymeric components (lignin, hemicellulose, and lignin) might be hydrolyzed from surface of the fiber to the middle and degrades successively (Wei and Meyer 2015). The mass loss at $350{ }^{\circ} \mathrm{C}$ for pure OPC is related with the dehydration of calcium hydroxide (Zheng et al. 2001). The initial peaks observed around $100{ }^{\circ} \mathrm{C}$ are associated with the dehydration of moisture present in the LF, cement, and composited panels. However, LF/cement showed significant weight loss between 270 and $350{ }^{\circ} \mathrm{C}$ where the magnitude is positively related with the fiber content. The second peaks around $330{ }^{\circ} \mathrm{C}$ for $\mathrm{LF}$ and composite panels are related with the decomposition of fibers. However, the peaks near $400{ }^{\circ} \mathrm{C}$ for $\mathrm{CBFB} 1$ and CBFB2 and around
$503{ }^{\circ} \mathrm{C}$ for $\mathrm{CBFB} 3$ and $\mathrm{CBFB} 4$ composite panels express the dehydration of calcium hydroxide $\left(\mathrm{Ca}(\mathrm{OH})_{2}\right)$. The dehydration of $\mathrm{Ca}(\mathrm{OH})_{2}$ within $420-500{ }^{\circ} \mathrm{C}$ is more evident when the volume of wood in the composites is lower (Wang et al. 2016). The higher porosity of LF-cement particles accelerates the constant diffusions of decreased $\mathrm{Ca}(\mathrm{OH})_{2}$ and $\mathrm{CO}_{2}$ easily for C-S-H decalcifications (Pizzol et al. 2014; Suazo et al. 2020). Portlandite can convert with the decomposition products of organic fibres (like plant fibers), for example into $\mathrm{Ca}(\mathrm{CO})_{3}$. In this regard, CBFB3 and CBFB4 composites (containing less LFs) exhibit more evident peaks than $\mathrm{CBFB} 1$ and $\mathrm{CBFB} 2$; however, the weight loss around $700-800{ }^{\circ} \mathrm{C}$ is associated with the breakdown of calcium carbonate $\left(\mathrm{CaCO}_{3}\right)$ through decarbonization. A similar phenomenon for cement bonded particle boards from different species of woods (spruce and poplar) was also expressed by previous researchers (Yel et al. 2020). However, the DTG curves (Fig. 11B) exhibit some peaks around $120-200{ }^{\circ} \mathrm{C}$, which are associated with the thermal decompositions of $\mathrm{CSH}$ (hydrated calcium silicate). The peaks around $362-382{ }^{\circ} \mathrm{C}$ indicate the decomposition of LFs both from the control and the composited matrix system. In addition, the peaks around 380 and $480{ }^{\circ} \mathrm{C}$ signal the dehydration of $\mathrm{Ca}(\mathrm{OH})_{2}$ (Lima et al. 2016). However, the thermal decomposition of Portlandites is indicated by the peaks around $480{ }^{\circ} \mathrm{C}$. A similar phenomenon for cement bonded particleboards production from balsa
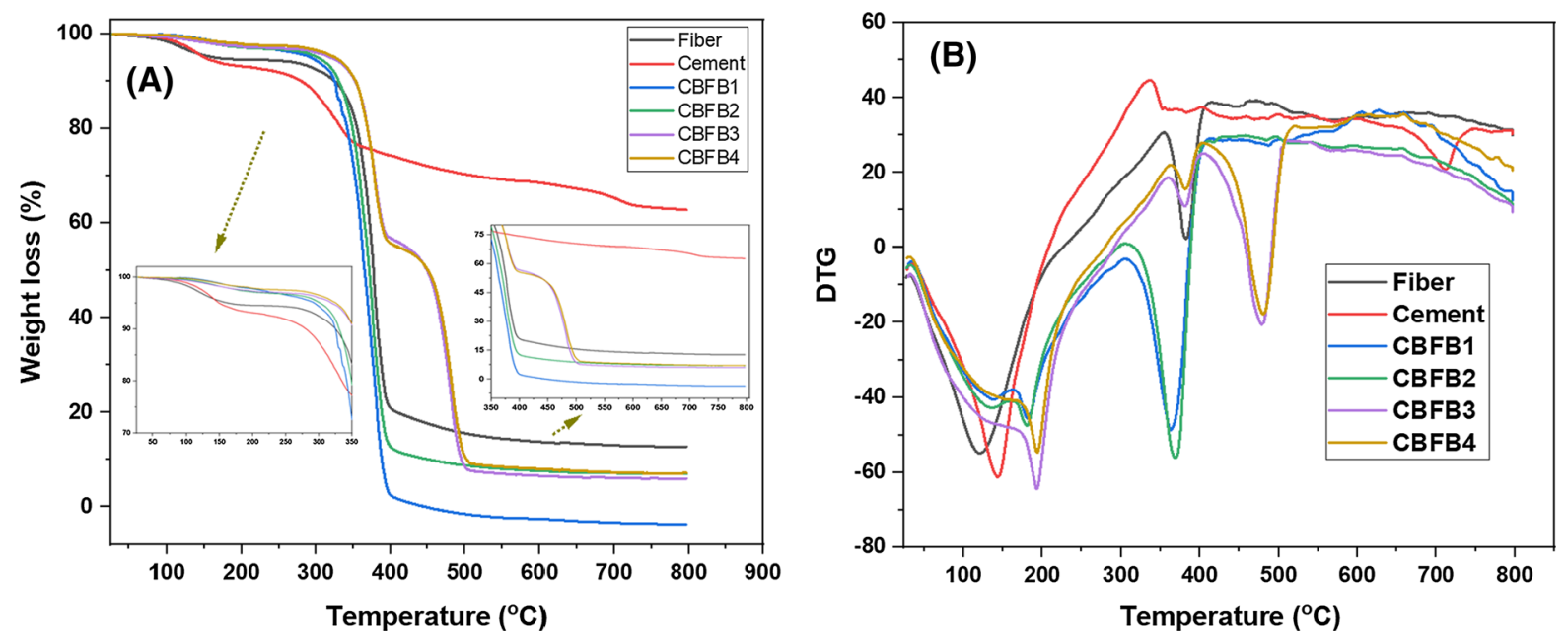

Fig. 11 Thermal analysis of LF/cement composites: a TGA and b DTG 
has been reported by other researchers (Cabral et al. 2018).

\section{Conclusions}

Interest in using natural fiber reinforced biocomposites in place of synthetic material-based composites to ensure an economical and environmentally sustainable option for the building and construction sector has been increasing steadily. Cellulose, lignin, and hemicellulose are the main chemical ingredients of any natural fibers/plants. From this perspective, the physical, morphological, mechanical, and thermal features of LF/cement composites have been investigated. The LFs were derived from seven different woody plants (beech, Turkey oak, pines, hornbeam, oaks, poplars, and other wood species), which were used in the production of cement bonded composites. As the variation in characteristics of LFs could generate incompatibility problems with the cement, different concentrations of OPCs were used with the LFs to discover the optimum ratio of LF/cement composites. The recipe for composite panel 2 was the most compatible compared to the other boards. The morphological and mechanical properties of developed composites found interesting. Another promising finding of this research is that all the developed composites provided the presence and characteristics of LFs, which is further confirmed by the SEM morphology and FTIR analysis (although a slight deformation from control LF is observed after reinforcing with cements). The thermal characterizations also prove the better stability of the composites in terms of thermal degradations along with accelerated carbonations after 28 days curing. The current work also discovered that the inclusion of more LFs facilitated the increase in mechanical performances, whereas the addition of more OPC into the proportions after 3.5 decreased mechanical features. Though some significant results for flexural and physical properties were found, further research to enhance fiber cement compatibility by modifying the surface of natural fibers and by using more compatible additives could be conducted.

Acknowledgments This work was supported by the "Stipendium Hungaricum" scholarship under the Simonyi Károly Faculty of Engineering, Wood Sciences, and Applied
Arts, University of Sopron, Hungary. This article was produced within the framework of "EFOP-3.6.1-16-2016-00018: improving the role of research, development, and innovation in the higher education through institutional developments assisting intelligent specialization in Sopron and Szombathely".

Funding Open access funding provided by University of Sopron.

\section{Compliance with ethical standards}

Conflicts of interest The authors declare that they have no conflicts of interest for the submitted work.

Open Access This article is licensed under a Creative Commons Attribution 4.0 International License, which permits use, sharing, adaptation, distribution and reproduction in any medium or format, as long as you give appropriate credit to the original author(s) and the source, provide a link to the Creative Commons licence, and indicate if changes were made. The images or other third party material in this article are included in the article's Creative Commons licence, unless indicated otherwise in a credit line to the material. If material is not included in the article's Creative Commons licence and your intended use is not permitted by statutory regulation or exceeds the permitted use, you will need to obtain permission directly from the copyright holder. To view a copy of this licence, visit http://creativecommons.org/licenses/by/4.0/.

\section{References}

Akhavan A, Catchmark J, Rajabipour F (2017) Ductility enhancement of autoclaved cellulose fiber reinforced cement boards manufactured using a laboratory method simulating the Hatschek process. Constr Build Mater 135:251-259. https://doi.org/10.1016/j.conbuildmat.2017. 01.001

Alpár T, Rácz I (2009) Production of cement-bonded particleboards from poplar (Populus euramericana cv.,,I 214 “). Drvna industrija: Znanstveni časopis za pitanja drvne tehnologije 60:155-160

Amiandamhen S, Meincken M, Tyhoda L (2016) Magnesium based phosphate cement binder for composite panels: a response surface methodology for optimisation of processing variables in boards produced from agricultural and wood processing industrial residues. Ind crops prod 94:746-754. https://doi.org/10.1016/j.indcrop.2016.09. 051

Antwi-Boasiako C, Ofosuhene L, Boadu KB (2018) Suitability of sawdust from three tropical timbers for wood-cement composites. J Sustain For 37:414-428. https://doi.org/10. 1080/10549811.2018.1427112

Arifuzzaman M, Kim HS (2015) Novel mechanical behaviour of perlite/sodium silicate composites. Constr Build Mater 93:230-240. https://doi.org/10.1016/j.conbuildmat.2015. 05.118

Asasutjarit C, Hirunlabh J, Khedari J, Charoenvai S, Zeghmati B, Shin UC (2007) Development of coconut coir-based 
lightweight cement board. Constr Build Mater 21:277-288. https://doi.org/10.1016/j.conbuildmat.2005.08.028

Ashori A, Tabarsa T, Azizi K, Mirzabeygi R (2011) Wood-wool cement board using mixture of eucalypt and poplar. Ind Crops Prod 34:1146-1149. https://doi.org/10.1016/j. indcrop.2011.03.033

Ashori A, Tabarsa T, Sepahvand S (2012) Cement-bonded composite boards made from poplar strands. Constr Build Mater 26:131-134. https://doi.org/10.1016/j.conbuildmat. 2011.06.001

Basher ABA (2013) Properties of Kenaf bast fibre cement composite board. Universiti Putra Malaysia

Bilcati GK, Matoski A, Trianoski R, Lengowski EC (2018) Effects of pre-treatment of Curauá fibers on compatibility with portland cements. Matéria (Rio de Janeiro). https:// doi.org/10.1590/s1517-707620180003.0524

Blankenhorn PR, Blankenhorn BD, Silsbee MR, DiCola M (2001) Effects of fiber surface treatments on mechanical properties of wood fiber-cement composites. Cem Concr Res 31:1049-1055. https://doi.org/10.1016/S00088846(01)00528-2

Bodirlau R, Spiridon I, Teaca CA (2007) Chemical investigation on wood tree species in a temperate forest, east-northern Romania. BioResources 2:41-57

Cabral MR, Nakanishi EY, dos Santos V, Gauss C, dos Santos SF, Fiorelli J (2018) Evaluation of accelerated carbonation curing in cement-bonded balsa particleboard. Mater Struct $51: 52$

de Klerk M, Kayondo M, Moelich G, de Villiers W, Combrinck R, Boshoff W (2020) Durability of chemically modified sisal fibre in cement-based composites. Constr Build Mater 241:117835. https://doi.org/10.1016/j.conbuildmat.2019. 117835

Evans T, Majumdar A, Ryder J (1981) A semi-dry method for the production of lightweight glass-fibre-reinforced gypsum. Int J Cem Compos Lightweight Concr 3:41-44

Ezerskiy V, Kuznetsova NV, Seleznev AD (2018a) Evaluation of the use of the CBPB production waste products for cement composites. Constr Build Mater 190:1117-1123

Fan M, Ndikontar MK, Zhou X, Ngamveng JN (2012) Cementbonded composites made from tropical woods: compatibility of wood and cement. Constr Build Mater 36:135-140. https://doi.org/10.1016/j.conbuildmat.2012. 04.089

Ferreira SR, de Andrade SF, Lima PRL, Toledo Filho RD (2017) Effect of hornification on the structure, tensile behavior and fiber matrix bond of sisal, jute and curauá fiber cement based composite systems. Constr Build Mater 139:551-561. https://doi.org/10.1016/j.conbuildmat.2016. 10.004

Ghofrani M, Mokaram KN, Ashori A, Torkaman J (2015) Fibercement composite using rice stalk fiber and rice husk ash: mechanical and physical properties. J Compos Mater 49:3317-3322. https://doi.org/10.1177\%2F0021998314 561813

Hasan K, Horváth PG, Alpár T (2020a) Potential natural fiber polymeric nanobiocomposites: a review. Polymers 12:1072. https://doi.org/10.3390/polym12051072

Hasan KMF, Horváth PG, Alpár T (2020b) Effects of alkaline treatments on coconut fiber reinforced biocomposites In: Dr. Csiszár Beáta HC, Kajos Luca Fanni, Kovács Olivér
Béla, Meżo Emerencia, Szabó Rebeka, Szabó-Guth Kitti (eds.), 9th Interdisciplinary doctoral conference, Pecs, Hungary, 27-28th November, 2020. Doctoral Student Association of the University of Pécs, p 241

Hasan KMF, Horváth PG, Alpár T (2021) Lignocellulosic fiber cement compatibility: a state of the art review. J Nat Fibers. https://doi.org/10.1080/15440478.2021.1875380

Hasan KMF, Péter GH, Gábor M, Tibor A (2021) Thermomechanical characteristics of flax woven fabric reinforced PLA and PP biocomposites. Green Mater. https://doi.org/ 10.1680/jgrma.20.00052

Hasan KMF, Péter György H, Tibor A (2020) Thermo-mechanical behavior of MDI bonded flax/glass woven fabric reinforced laminated composites. ACS Omega. https://doi. org/10.1021/acsomega.0c04798

He P, Poon CS, Tsang DC (2020) Water resistance of magnesium oxychloride cement wood board with the incorporation of supplementary cementitious materials. Constr Build Mater 255:119145. https://doi.org/10.1016/j.conbuildmat. 2020.119145

Hospodarova V, Singovszka E, Stevulova N (2018) Characterization of cellulosic fibers by FTIR spectroscopy for their further implementation to building materials. Am J Analyt chem 9:303-310. https://doi.org/10.4236/ajac.2018.96023

Karade S, Aggarwal L (2011) Cement-bonded lignocellulosic composites for building applications. Metals Mater Process 17:129

Kochova K, Caprai V, Gauvin F, Schollbach K, Brouwers H (2020) Investigation of local degradation in wood stands and its effect on cement wood composites. Constr Build Mater 231:117201. https://doi.org/10.1016/j.conbuildmat. 2019.117201

Kochova K, Gauvin F, Schollbach K, Brouwers H (2020) Using alternative waste coir fibres as a reinforcement in cementfibre composites. Constr Build Mater 231:117121. https:// doi.org/10.1016/j.conbuildmat.2019.117121

Kostić S, Meier S, Cabane E, Burgert I (2018) Enhancing the performance of beech-timber concrete hybrids by a wood surface pre-treatment using sol-gel chemistry. Heliyon 4:e00762. https://doi.org/10.1016/j.heliyon.2018.e00762

Kumar TSM, Rajini N, Reddy KO, Rajulu AV, Siengchin S, Ayrilmis N (2018) All-cellulose composite films with cellulose matrix and Napier grass cellulose fibril fillers. Int J Biol Macromol 112:1310-1315. https://doi.org/10.1016/ j.ijbiomac.2018.01.167

Li Q, Ibrahim L, Zhou W, Zhang M, Fernando GF, Wang L, Yuan Z (2020) Holistic solution to natural fiber deterioration in cement composite using hybrid treatments. Cellulose 27:981-989. https://doi.org/10.1007/s10570-01902813-2

Lima PR, Santos DO, Fontes CM, Barros JA, Toledo Filho RD (2016) Deflection hardening of sustainable fiber-cement composites. Green Materials 4:18-30

Mahmud S, Hasan KMF, Jahid MA, Mohiuddin K, Zhang R, Zhu J (2021) Comprehensive review on plant-fiber reinforced polymeric biocomposites. J Mater Sci 56:7231

Małaszkiewicz D, Sztukowska M (2018) Utilization of wastes from medium density fiberboards production as an aggregate for lightweight cement composite. In: Matec web of conferences, EDP Sciences, p 02005 
Marques ML, Luzardo FH, Velasco FG, González LN, Silva EJd, Lima WGd (2016) Compatibility of vegetable fibers with Portland cement and its relationship with the physical properties. Rev Bras Eng Agrícola Ambient 20:466-472. https://doi.org/10.1590/1807-1929/agriambi.v20n5p466472

Monlar Sandor BM (2002) Softwoods, Hardwoods. In: Ildiko K (ed.), Wood species of Hungary. Szaktudas Kiado Haz Rt., Budapest, Hungary

Na B, Wang Z, Wang H, Lu X (2014) Wood-cement compatibility review. Wood Res 59:813-826

Onuaguluchi O, Banthia N (2016) Plant-based natural fibre reinforced cement composites: a review. Cem Concr Compos 68:96-108. https://doi.org/10.1016/j. cemconcomp.2016.02.014

Papadopoulos AN (2008) Mechanical properties and decay resistance of hornbeam cement bonded particleboards. Res Lett Mater Sci. https://doi.org/10.1155/2008/379749

Pereira TGT et al (2020) Coconut fibers and quartzite wastes for fiber-cement production by extrusion. Mater Today. https://doi.org/10.1016/j.matpr.2020.01.394

Phomrak S, Phisalaphong M (2020) Lactic acid modified natural rubber-bacterial cellulose composites. Appl Sci 10:3583. https://doi.org/10.3390/app10103583

Pizzol V, Mendes L, Frezzatti L, Savastano H Jr, Tonoli G (2014) Effect of accelerated carbonation on the microstructure and physical properties of hybrid fiber-cement composites. Miner Eng 59:101-106

Quiroga A, Marzocchi V, Rintoul I (2016) Influence of wood treatments on mechanical properties of wood-cement composites and of Populus Euroamericana wood fibers. Compos B Eng 84:25-32. https://doi.org/10.1016/j. compositesb.2015.08.069

R. wagenfuhr CS (1989) In: Holzatlas

Ranachowski Z, Schabowicz K (2017) The contribution of fiber reinforcement system to the overall toughness of cellulose fiber concrete panels. Constr Build Mater 156:1028-1034. https://doi.org/10.1016/j.conbuildmat.2017.09.067

Simatupang MH, Geimer RL (1990) Inorganic binder for wood composites: feasibility and limitations. In: Proceedings of wood adhesive symposium, Forest Product Resources Society, p 176

Sood M, Dwivedi G (2018) Effect of fiber treatment on flexural properties of natural fiber reinforced composites: a review. Egypt J pet 27:775-783. https://doi.org/10.1016/j.ejpe. 2017.11.005
Soroushian P, Hassan M (2012) Evaluation of cement-bonded strawboard against alternative cement-based siding products. Constr Build Mater 34:77-82. https://doi.org/10. 1016/j.conbuildmat.2012.02.011

Soroushian P, Won J-P, Hassan M (2012) Durability characteristics of $\mathrm{CO}_{2}$-cured cellulose fiber reinforced cement composites. Constr Build Mater 34:44-53. https://doi.org/ 10.1016/j.conbuildmat.2012.02.016

Suazo FJA, Carregosa JDC, Oliveira RMPB, Acchar W (2020) Mechanical performance and healing process improvement of cement-coir pith particle composites by accelerated carbonation. Matéria (Rio de Janeiro). https://doi.org/10. 1590/s1517-707620200002.1069

Takats P, Takats A (2012) Utilisation of fiber sludge refuse in gypsum fiberboards. In: International scientific conference March, pp 26-27

Tichi AH, Bazyar B, Khademieslam H, Rangavar H, Talaeipour M (2019) Is wollastonite capable of improving the properties of wood fiber-cement composite? BioResources 14:6168-6178. https://doi.org/10.15376/biores.14.3.61686178

Wang L, Chen SS, Tsang DC, Poon CS, Shih K (2016) Valueadded recycling of construction waste wood into noise and thermal insulating cement-bonded particleboards. Constr Build Mater 125:316-325

Wei J, Meyer C (2015) Degradation mechanisms of natural fiber in the matrix of cement composites. Cem Concr Res 73:1-16. https://doi.org/10.1016/j.cemconres.2015.02.019

Yel H, Cavdar AD, Torun SB (2020) Effect of press temperature on some properties of cement bonded particleboard. Maderas Cienc Tecnol. https://doi.org/10.4067/S0718221X2020005000108

Zheng L, Du Y, Zhang J (2001) Degumming of ramie fibers by alkalophilic bacteria and their polysaccharide-degrading enzymes. Bioresour Technol 78:89-94. https://doi.org/10. 1016/S0960-8524(00)00154-1

Zhou Y, Kamdem DP (2002) Effect of cement/wood ratio on the properties of cement-bonded particleboard using CCAtreated wood removed from service. For Prod J 52:77

Publisher's Note Springer Nature remains neutral with regard to jurisdictional claims in published maps and institutional affiliations. 